著明な低 $\mathrm{Ca}$ 血症を伴った蛋白漏出性胃腸症の一例

\author{
兵庫県立成人病センター 代謝・内分泌内科1)・同検査部2) \\ 島扶美1), 石田芳 彦1), 吉田玲子1) \\ 穂 積 俊 樹1), 大 川二 郎2), 鹿 住 敏1)
}

\title{
Severe hypocalcemia in a patient with protein-losing enteropathy
}

\author{
Fumi SHIMA $^{1)}$, Yoshihiko ISHIDA ${ }^{1)}$, Reiko YOSHIDA ${ }^{1)}$, \\ Toshiki HOZUMI'), Jiro OHKAWA ${ }^{2)}$, Tsutomu KAZUMI ${ }^{1)}$ \\ 1)Division of Endocrinology and Metabolism, Department of Medicine \\ ${ }^{2)}$ Department of Pathology, Hyogo Medical Center for Adults
}

We report a 53-year-old woman with hypocalcemia associated with protein-losing enteropathy. She had had lymphedema of the left lower extremity since 20 years of age and had loose bowels and hypoproteinemia. Her daily fecal excretion of $\alpha_{1}$-antitrypsin was extremely high, suggesting massive intestinal protein loss. This was demonstrated by scintigraphy using ${ }^{99} \mathrm{~m}$ Tc-labeled human serum albumin, in which significant amounts of radioactivity were first accumulated in the lower part of the small intestine and then went down along the colon. She not only had hypocalcemia, but also an increased serum concentration of immunoreactive parathyroid hormone $(\mathrm{PTH})$ and 1,25 (OH $)_{2} \mathrm{D}$, and increased percent tubular reabsorption of phosphate. In addition, she had low serum levels of fat-soluble vitamins including $25(\mathrm{OH}) \mathrm{D}$. In the Ellsworth-Howard test, urinary excretion of cyclic AMP and phosphate in response to exogenous PTH was rather exaggerated. These results suggest that hypocalcemia in this case was due mainly to malabsorption of calcium and vitamin D secondary to protein-losing enteropathy.

Keywords: secondary hyperparathyroidism, hypocalcemia, protein-losing enteropathy, intestinal lymphangiectasia

\section{は じめ に}

蛋白漏出性胃腸症は，アルブミンが腸管内に漏出する事によって起こる低蛋白血症が惹起する症候 群1)であるが，その病態及び病因は多種多様である。今回我々は，先天性腸リンパ系異常が疑われ， 蛋白漏出性胃腸症によるカルシウム $(\mathrm{Ca})$ とビタミン D の吸収不全を伴った続発性副甲状腺機能六 進症2)と考えられる症例を経験したのでここに報告する。

\section{症例}

患 者: 53 才, 女性。

主 訴: 下痢, 左下肢浮腫。 
家族歴：特記すべき事なし。

既往歴 : 7 才: 先天性肺動脈狭窄症を指摘。

$$
35 \text { 才, } 46 \text { 才: 肺結核。 }
$$

現病歴 : 7 才頃より運動時呼吸困難, 顔面, 両下肢の浮腫を自覚するようになり, 近医で先天性肺動 脈狭窄症を指摘された。20才頃より左足首の腫脹を自覚するよらになり，28才時，左下肢全体に浮 腫が著明となった。48 才頃よりさらに下痢症状が出現し，低蛋白血症が著明となったため入院とな った。

入院時現症: 身長 $153 \mathrm{~cm}$, 体重 $51 \mathrm{~kg}$, 体温 $35.6^{\circ} \mathrm{C}$ 。左下肢全体に non-pitting edema を認めたが, 色調変化や潰瘍形成なし。また第 2 肋間胸骨左縁で Levein III / VI の駆出性収縮期雑音を聴取した。 腹部に特に異常所見なし。神経学的所見としては四肢の強直性痤攣，不随意運動は認めなかったが, Chvostek’s sign 陽性, Trousseau’s sign 陽性，四肢末端の疩れ感と皮膚知覚過敏を認めた。

入院時検查成績 (Table 1): 糞便検查で潜血反応陰性であるが，脂肋球を多数認めた。また $\alpha_{1}$ アンチ

Table 1 Laboratory findings on admission

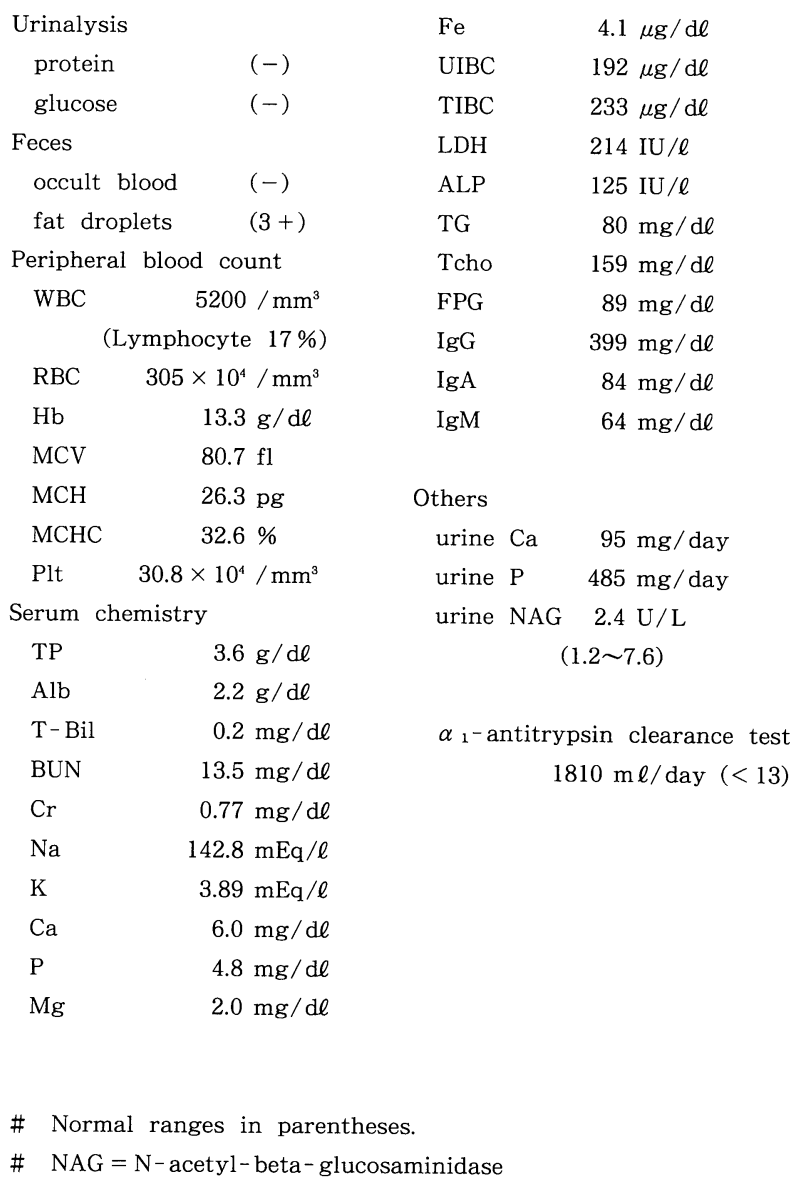


トリプシンクリアランステスト ${ }^{3)}$ では陽性を認め, 血液生化学検査では著明な低蛋白血症を認めた。 また血清 $\mathrm{Ca} 6.0 \mathrm{mg} / \mathrm{dl}$ (アルブミン補正值 $7.8 \mathrm{mg} / \mathrm{dl}$ ), 血清リン (P) $4.8 \mathrm{mg} / \mathrm{dl}$ を呈していたが, 肝機能，腎機能は特に異常所見を認めず，マグネシウム $(\mathrm{Mg})$ も正常であった。また，心電図では $\mathrm{QT}$ 時間の延長 $(\mathrm{QTc}=455 \mathrm{~ms})$ を認めた。

内分泌学的検查 (Table 2): 副甲状腺ホルモン (PTH 中間部：M-PTH $\left.{ }^{4}\right)$ は $1700 \mathrm{pg} / \mathrm{ml}$ と高值を示し た。カルシトニン, 成長ホルモン, プロラクチンに異常值は認めなかった。甲状腺ホルモンは正常範 囲であるが，甲状腺刺激ホルモンは軽度高值を示して扣り, subclinical hypothyroidism と考劣られ た。また尿細管リン再吸収率 (Percent Tubular Reabsorption of Phosphate: \%TRP) は $99 \%$ と高值 を示していた。Ellsworth-Howard 試験では，尿中 cyclic AMP 反応はPTH 投与前後 1 時間の差： $\left(\mathrm{U}_{4}-\mathrm{U}_{3}\right)$ は $11 \mu \mathrm{mol} / 1$ hour (正常 $1 \mu \mathrm{mol} / 1$ hour 以上), 前後 1 時間の比: $U_{4} / \mathrm{U}_{3}$ は 56 倍（正常 10 倍以上）で,リン酸反応は前後 2 時間の差: $\left(U_{4}+U_{5}\right)-\left(U_{2}+U_{3}\right)$ は $107 \mathrm{mg} / 2$ hour（正常 $35 \mathrm{mg}$ / 2 hour 以上）で外因性 PTH 飞対する反応は保たれていた。脂溶性ビタミン A，D，E，はすべて低 值を示したが (Table 2), 特に $25(\mathrm{OH}) \mathrm{D}$ は $6 \mathrm{ng} / \mathrm{ml}$ 以下と低值を示し, 一方, $1 \alpha, 25(\mathrm{OH})_{2} \mathrm{D}$ は $80 \mathrm{pg} / \mathrm{ml}$ と比較的高值を示した。

Table 2 Endocrinological findings

$\begin{array}{lrl}\mathrm{M}-\mathrm{PTH} & 1700 \mathrm{pg} / \mathrm{m} \ell & (130-490) \\ \text { Calcitonin } & 49 \mathrm{pg} / \mathrm{m} \ell & (<80) \\ \mathrm{T}_{3} & 1.04 \mathrm{ng} / \mathrm{m} \ell & (0.8-1.8) \\ \mathrm{T}_{4} & 8.5 \mu \mathrm{g} / \mathrm{d} \ell & (4.6-12.6) \\ \mathrm{FT}_{4} & 0.9 \mathrm{ng} / \mathrm{d} \ell & (0.85-2.15) \\ \mathrm{TSH} & 5.82 \mu \mathrm{IU} / \mathrm{m} \ell & (0.6-5.1) \\ \% \mathrm{TRP} & 99 \% & (80-96) \\ \text { Cortisol } & 8.1 \mu \mathrm{g} / \mathrm{d} \ell & (4.4-7.4) \\ \mathrm{PRL} & 14 \mathrm{ng} / \mathrm{m} \ell & (5-27) \\ 25(\mathrm{OH}) \mathrm{D} & <6 \mathrm{ng} / \mathrm{m} \ell & (10-30) \\ 1,25(\mathrm{OH})_{2} \mathrm{D} & 80 \mathrm{pg} / \mathrm{m} \ell & (25-50) \\ \text { Vitamin } \mathrm{A} & 82 \mathrm{IU} / \mathrm{d} \ell & (103-354) \\ \text { Vitamin E } & 2 \mu \mathrm{g} / \mathrm{m} \ell & (7-17) \\ \text { NcAMP } & 1.95 \mu \mathrm{mol} / \mathrm{day} & (3.1-7.1)\end{array}$

Ellsworth-Howard test

Phosphate excretion :

$$
\begin{array}{r}
\left(\mathrm{U}_{4}+\mathrm{U}_{5}\right)-\left(\mathrm{U}_{2}+\mathrm{U}_{3}\right)=107 \mathrm{mg} / 2 \mathrm{hr} \\
(>35 \mathrm{mg} / 2 \mathrm{hr})
\end{array}
$$

c- AMP excretion :

$\mathrm{U}_{4}-\mathrm{U}_{3}=11 \mu \mathrm{mol} / \mathrm{hr}$

(>1 $\mu \mathrm{mol} / 1 \mathrm{hr})$

$$
\mathrm{U}_{4}-\mathrm{U}_{3}=56 \quad(>10)
$$

$\mathrm{Tmp} / \mathrm{GFR} \quad 4.8 \mathrm{mg} / \mathrm{d} \boldsymbol{\ell}$

\# TRP = Tubular Reabsorption of Phosphate.

\# Normal ranges in parentheses.

\# NcAMP $=$ Nephrogenous cyclic AMP

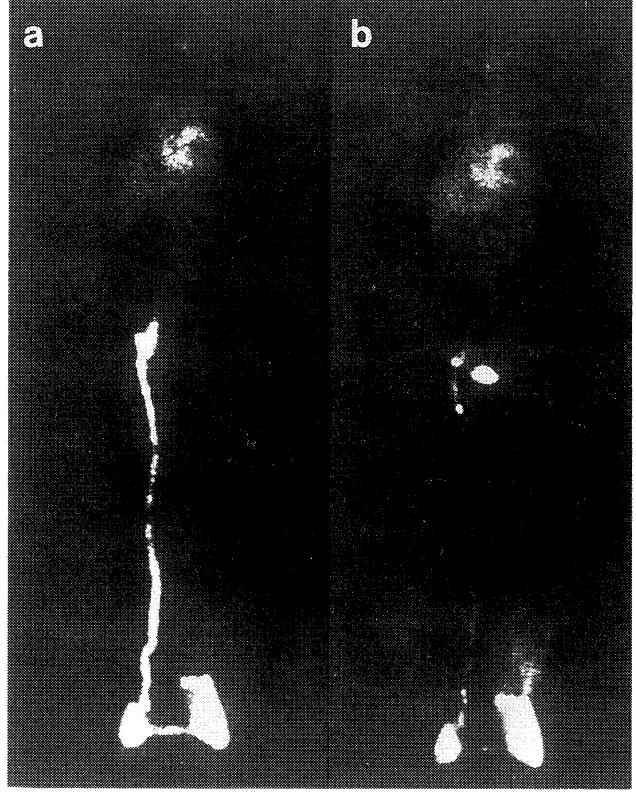

Fig. 1 Lymphoscintigrams with $99 \mathrm{~m}$ Tc-diethylene triamine pentaacetic acid-human serum albumin showing discontinuous lymphatic flow on the left lower extremity (a). However, abnormal uptake was not demonstrated in the abdominal region (b). 
リンパシンチ5) (Fig. 1) では，左下肢のリンパ流の著明な障害がみられたが，腹腔内のリンパのう っ滞は観察されなかった。しかし, $99 \mathrm{mT}$ Tc-Diethylene Triamine Pentaacetic Acid-Human Serum Albumin ( ${ }^{99} \mathrm{~m}$ Tc-DTPA-HSA) を用いた出血シンチ6) (Fig. 2) では 5 時間後より下腹部への軽度の集積 が見られ始め, 24 時間後には盲腸, 上行結腸, 横行結腸に集積が拡がり, 腸管腔内への著明なアル ブミンの漏出を認めた。一方, 上, 下腹部消化管内視鏡検査に挆いては, 下行結腸に直径約 $5 \mathrm{~mm}$ の腺腫を 5 個と, 軽度の回腸末端炎を認めるのみで, 著明な蛋白漏出を示唆する所見は認められなか った。骨シンチでは，アイソトープの骨への集積は全体的に増加するとともに，左下肢の皮下組織と 腸管に異常集積像を認めた (Fig. 3)。な扎，上，下腹部 CT では特記すべき所見を認めなかった。

臨床経過 (Fig. 4) : 対症的にビタミン D 製剂, カルシウム製剂の内服と当初 8 ケ月間は, 中鎖脂肪酸 トリグリセライド (Medium Chain Triglyceride: MCT) 食) とて栄養状態の改善を計った。通常, 長 鎖脂肪酸は消化管より吸収された後はリンパ流に入り，大循環へ運ばれる吸収経路をとるが， MCT は消化吸收後大部分が門脈系へ移行するといら吸収特性をもっており, 本例の如くリンパ流の障害が 推定された場合有用と考光用いた。結果, 血清 Ca の増加と血清 P の減少傾向並びに M-PTH の漸 減傾向が認められた。しかし，'93，12月にらっ血性心不全を来し，一時的に栄責状態不良になり，

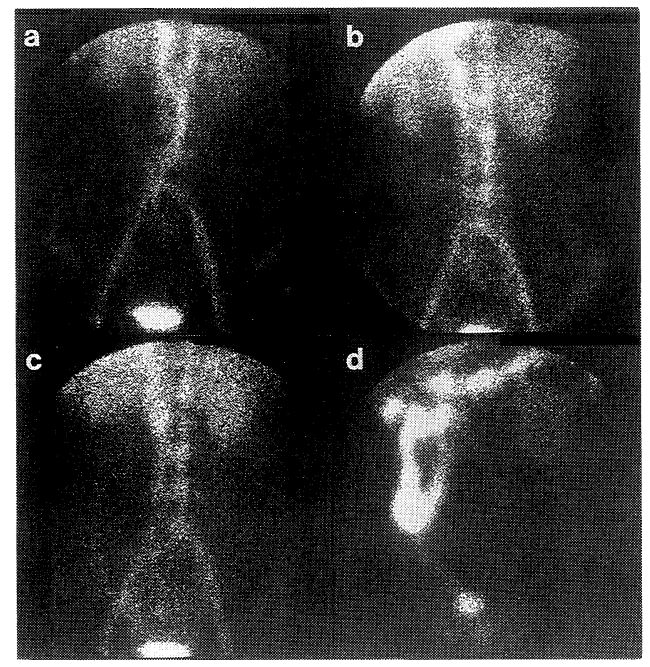

Fig. 2 Scintigrams with ${ }^{99} \mathrm{~m}$ Tc-diethylene triamine pentaacetic acid-human serum albumin. Radioactivity was not observed in the small intestine, at 30 minutes (a) and 1 hour (b). However, significant amounts of activity were accumulated in the lower part of small intestine at 5 hours (c) and went down along the colon at 24 hours (d).

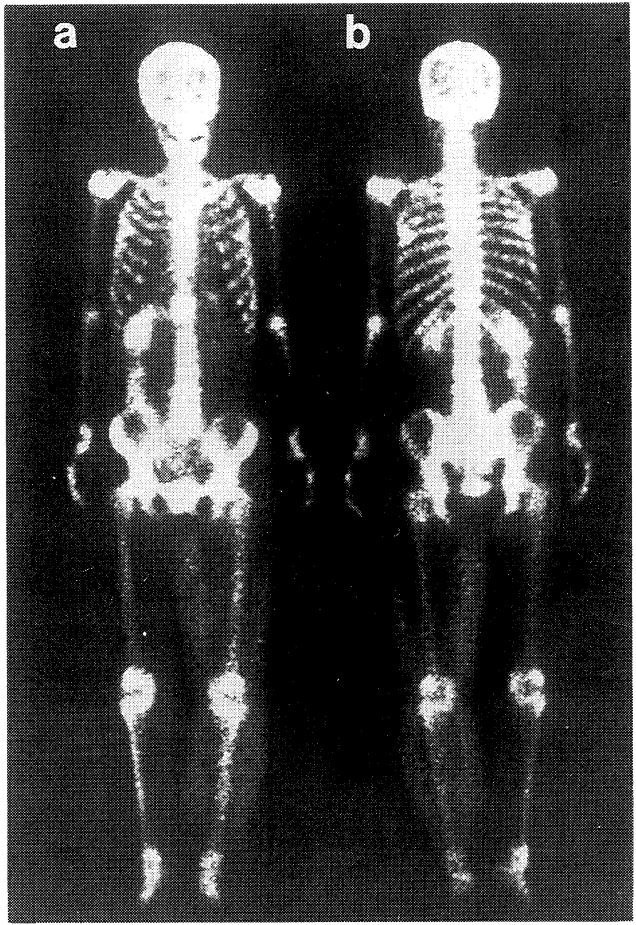

Fig. 3 Bone scintigrams with $99 \mathrm{~m}$ Tc-methylene diphosphonate showing intense uptake over the entire body, particularly in the vertebrae $(a, b)$, subcutaneous tissue of the left lower extremity (a) and in the large intestine (a). 


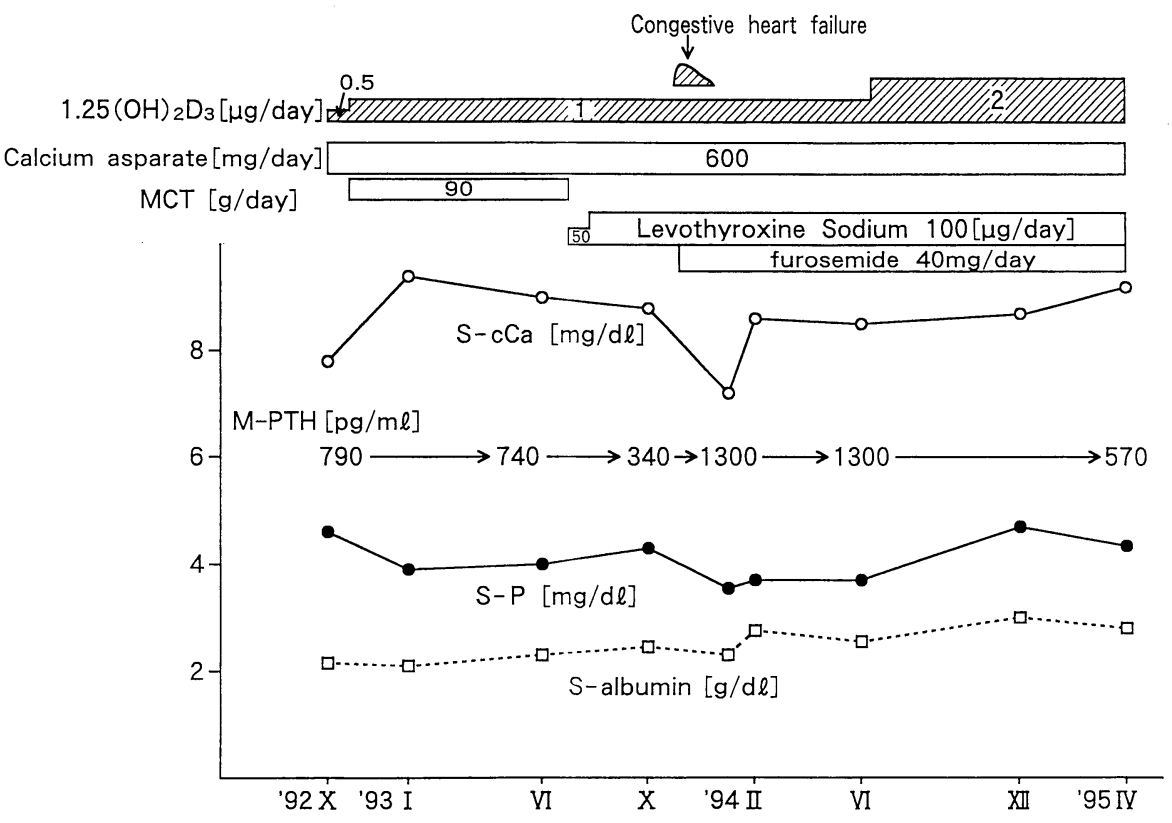

Fig. 4 Clinical course of a patient with idiopathic pseudohypo-parathyroidism associated with protein-losing enteropathy. MCT; medium chain triglycerides.

$\mathrm{cCa}$; serum calcium corrected for serum albumin.

その際一過性に低 Ca 血症, そ机に併行して血清 M-PTH も上昇したが，利尿剤にてらっ血性心不 全のコントロール後, 小康状態を得ている。

\section{考察}

まず低タンパク血症の原因であるが，検便にて便中に脂肪滴を認め，肝障害，腎障害を認めず血清 総タンパク，アルブミン，免疫グロブリンが低值を呈した為，消化管からの漏出を疑った。 $\alpha_{1}$-アン チトリプシンテストでは $1810 \mathrm{ml} /$ 日と陽性を呈した為, 消化管へのタンパク漏出と診断した。

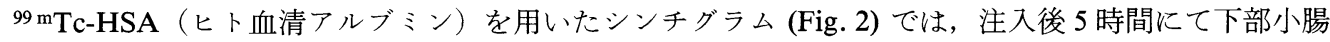
より放射活性が認められ，24 時間後には大腸全域に集積が認められた為，下部小腸からの漏出を疑 った。次いで漏出の部位を調べる目的で，内視鏡検査にて食道，胃，十二指腸上部，回腸末端部，大 腸を検索したが，Kerckling 㱀壁の腫大，多発性小隆起，散在性白点といった肉眼像は得られなかっ

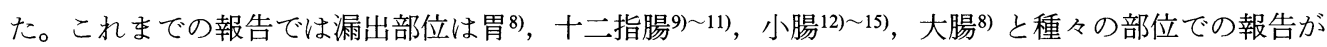
認められる。本例は消化管内視鏡検查の際，口側は十二指腸上部をで，肛門側は回腸の回盲部より $50 \mathrm{~cm}$ 口側までしか検索し得なかった為, 漏出部位の確定に至らなかったものと考吕られた。さらに， タンパク漏出の基礎疾患であるが，若年時よりリンパ浮腫を認めた事，リンパシンチにて左下肢にリ ンパ流の障害が認められた事より，Waldmann らが提唱したリンパ管形成不全による原発性腸管リ ンパ管拡張症 ${ }^{1)}$ によるものと推定している。

次に, 本例で認められる $\mathrm{Ca}$ 代謝異常であるが, 低 $\mathrm{Ca}$ 血症, 高 P 血症を呈し, M-PTH が増加し 
ている事より, 続発性副甲状腺機能充進症, 偽性副甲状腺機能低下症, 偽性特発性副甲状腺機能低下 症が考光られた。Ellswotrh-Howard テストの結果, 尿 cyclic AMP, 尿リン酸反応共に良好であった 事より，まず偽性副甲状腺機能低下症が否定された。タンパク漏出による吸収不全は， Ca，P の吸 収不全, ビタミン D の吸収低下, 肝から胆汁中に排泄されたビタミン D, $25(\mathrm{OH}) \mathrm{D}$ の腸管吸収の 低下をもたらし続発性副甲状腺機能充進症を引き起こす事がいわれている16)。本例では低 Ca 血症の 割に一日尿中 Ca 排泄 $95 \mathrm{mg}$ / 日と高值である事(翌日尿 Ca 排泄 $167 \mathrm{mg}$ / 日, 同 P 排泄 $303 \mathrm{mg}$ / 日), \%TRP が高值であること, 尿中 cAMP 排泄が低下している事が続発性副甲状腺機能低下症を支持し ない所見であるが，入院前より投与を受けていたビタミン D 製剤の影響が大きいと考兄られた。本 例の Ca 代謝は消化管での吸收障害, 腎尿細管での内因性 PTH に対する反応性, 骨の remodeling (オ ステオカルシン $9.2 \mathrm{ng} / \mathrm{ml}$ の軽度上昇, アルカリフォスファターゼは正常）等の因子が複雑に関連 している病態と考えられた。以上より本例の低 $\mathrm{Ca}$ 血症の原因として続発性副甲状腺機能低下症が最 も疑わしいと考兄られるが，外因性 PTH に対する反応は正常ながら，内因性 PTH に対する反応不 良（腎原性 cyclic AMP 基礎值低下）も疑われ，稀ではあるが偽性特発性副甲状腺機能低下症 ${ }^{17)} の$ 可能性も考慮に入れる必要があると考光られた。

\section{文献}

1) Waldmann, T.A.: Protein-losing gastroenteropathies. In Bockus Gastroenterology, 4 th Ed., ed. by J.E. Berk, W.B. Saunders, Philadelphia, 1985; $1814-1837$

2) Nusynowitz, M.L., Klein, M.H.: Pseudoidiopathic hypoparathyroidism. Hypoparathyroidism with ineffective parathyroid hormone. Am. J. Med. 1973; 55: $677-686$

3) Crossley, Jr., Elliot, R.B.: Simple method for diagnosing protein losing enteropathies. Brit. Med. J. 1977; II: $428-429$

4) 深瀬正晃, 藤田拓男, 松本俊夫, 尾形悦郎, 飯島 隆, 竹沢順一, 斎藤健一, 石毛英幸, 藤本正雄 : 高感度 PTH 測定 法による健常者の血中 PTH 動態之各種疾患の病態解析. 日内分泌会誌. 1989; 65: 807-827

5) 白神宜史, 松本康浩, 山内優子, 倉見美規, 上田信夫, 葉杖正昭 : 心プールスキャンニング剤 $99 \mathrm{mTc}$-DTPA-HSA 注射 液の開発. 核医学. 1987; 24: $475-477$

6) Divigi, C.H., Lisann, N.M., Yeh, S.D., Benua, R.S.: Technetium- $99 \mathrm{~m}$ albumin scintigraphy in the diagnosis of proteinlosing enteropathy. J. Nucl. Med. 1986; 27: 1710-1712

7) 土屋雅春, 朝倉 均, 宮入 守, 三浦総一郎, 吉岡政洋 : 腸管リンパ系の基礎と臨床. リンパ学. 1983; 6: 203-210

8) 村上俊吾, 石谷邦彦, 水島康博, 吉田憲基 : 腸リンパ管拡張症が原因と考えられた蛋白漏出性胃腸症の 1 例. 日消病 会誌. 1993; 90: 2415

9) 高橋雅彦, 山崎雄一郎, 中西孝至, 筒井秀作, 前田祐一, 奥野 優, 金山周次, 篠村恭久, 松沢佑次, 磯, 上正明 : 表皮母玟症候群に合併した原発性リンパ管拡張症の 1 症例. 日消病会誌. 1993; 90: 1038

10）菅原光宏, 折居正之, 片山佐登志, 滝川康裕, 阿部弘一, 山田宏之, 加藤智恵子, 田澤秀樹, 大澤一嘉, 遠山 潤, 佐藤邦夫，佐藤俊一：腸リンパ管拡張症によると思われた蛋白漏出性胃腸症の一例. 日消病会誌. 1993; 90: 1069

11) 青柳邦彦, 飯田三雄, 富永雅也, 松本圭之, 藤島正敏, 八尾隆史, 岡田光男, 松井敏幸 : 腸リンパ管拡張症 6 例の臨 㦿像. Gastroenterological endoscopy 1993; 35: 3050-3051

12）柏木昭人, 松浦 昭, 白井正人, 中村常哉, 高木 篤, 小林世美：腸管リンパ管拡張症の 1 例. 日消病会誌. 1993; 90: 2414

13) 田嶋美香, 堀田総一, 瀬尾由広, 鴨志田敏郎, 平井信二, 岡 裕爾, 伴 慎一, 高橋 敦: 原発性腸リンパ管拡張症 による蛋白漏出性腸症の 1 症例. 日立医誌. 1994; 32 (1): 6-10

14）加藤典弘, 塚田 博, 大野富雄, 林 陸郎, 伴野祥一, 鈴木 忠, 村田和彦, 今成哲郎, 小暮晴一郎, 土屋幸彦: て んかん発作を初発症状とした原発性腸リンパ管拡張症の 1例. 日内会誌. 1988; 77: $51-54$

15) 安藤和子, 杉田泰雄, 金子健蔵, 石川三衛, 斎藤公司, 岩本安彦, 坂本美一, 山本邦宏, 松田文子, 斎藤寿一, 葛谷 健, 小林誠一：インスリン依存性糖尿病, 特発性副甲状腺機能低下症, 成長ホルモン分泌低下と多彩な内分泌腺機能 


$$
\text { 日本内分泌学会雑誌 }
$$

低下を示し，タンパク漏出性腸リンパ管払張症を伴った 1 例. 内科. 1987; 59: 1171-1175

16）清野佳紀：ビタミン D 代謝異常. 日内会誌. 1993; 82: 17-22

17) 山本通子, 古川洋太郎, 田村 泰, 清野佳紀, 五十嵐良雄, 藤田拓男, 尾形悦郎, 井村裕夫 : 偽性副甲状腺機能低下 症の各種病型拉よび類縁疾患の診断基準. 日内分泌会誌. 1982; 58: 1080-1094

（受付日：'94, 5, 31)

(採択日 : '95, 10, 24) 